\title{
ДОСВІД ЄВРОПЕЙСЬКОГО СОЮЗУ У ПИТАННЯХ АДМІНІСТРУВАННЯ МИТНИХ ПЛАТЕЖІВ: ТЕОРЕТИЧНІ ОСНОВИ ТА ПРАКТИЧНІ РЕКОМЕНДАЦІЇ
}

\author{
Прокіпчук Левко Ігорович \\ аспірант \\ Львівський національний університет імені Івана Франка (м.Львів, Україна) \\ ORSID 0000-0003-3979-3100 \\ prokipchuk0017@gmail.com
}

У статті досліджено досвід Європейського Союзу у питаннях адміністрування митних платежів. Визначено основні категорії митних платежів, які справляються на території ЄС (імпортне мито; експортне мито; антидемпінгове мито; компенсаційне мито; сільськогосподарські мита; податок на додану вартість; акцизи). Розглянуто критерії за якими можна класифрікувати мита у ЄС (за характером зовнішньоекономічних операцій (імпортні, експортні), за способом встановлення ставок (адвалерні, специфрічні, змішані), сільськогосподарські мита (постійні, сезонні), за цілями стягнення (звичайні, спеціальні)). Досліджено питання справляння податку на додатку вартість та акцизного збору у країнах Співтовариства. Зазначено види послуг за які митне законодавство ЄС допускає у ряді випадків стягнення митними органами держав-членів митних зборів як плату за додаткові послуги. Запропоновано заходи спрямовані на підвищення організації роботи з адміністрування митних платежів в країнах ЄC.

Ключові слова: митні платежі, податок на додану вартість, а, адміністрування, європейський Союз.

DOI: https://doi.org/10.32845/bsnau.2019.3.12

Постановка проблеми. Глобалізаційні процеси щодня розширюють свої межі, що сприяє розвитку економіки держав, зростанню науково-технічного прогресу, перерозподілу трудових ресурсів, товарній глобалізації та створює ряд інших передумов для соціально-економічного розвитку держав-членів Європейського Союзу. Кінцевим результатом такого процесу повинно стати вільне переміщення товарів, послуг, об'єктів інтелектуальної власності, капіталів, робочоі сили через території різних держав і поступове зникнення торгових бар'єрів між ними. Такі зміни поступово запроваджуватимуться і в національній економіці, що сприятиме розвитку партнерських стосунків між Україною та країнами Співтовариства.

Аналіз останніх досліджень і публікацій. Проблематика адміністрування митних платежів на території Європейського Союзу та можливості впровадження кращих практик в Україні все частіше привертає до себе увагу вітчизняних вчених. До неї неодноразово зверталися такі українські науковці, як Денисенко В., Крисоватий А., Мазур А., Семенчук Н., Юрій С. та ін. Водночас наукові розробки у галузі митної справи та можливості впровадження кращих міжнародних практик не охоплюють увесь спектр проблем, відтак, потребують поглибленого вивчення та надання пропозицій щодо імплементації в українське законодавство.

Метою статті є дослідження європейського досвіду у питаннях адміністрування митних платежів.

Виклад основного матеріалу. Митні платежі котрі справляються у Європейському Союзі можна розділити на наступні категорії [1]:

- імпортне мито;

- експортне мито;

- антидемпінгове мито;

- компенсаційне мито;

- сільськогосподарські мита;

- податок на додану вартість;

- акцизи.

Ще одним різновидом митних платежів є митні збори, котрі сплачуються за митне оформлення товарів, однак митні

збори не надходять до бюджету Співтовариства, так як правовою основою їх встановлення $€$ нормативно-правове законодавство окремих країн членів $€$.

Основною метою справляння мита на території Європейського Союзу є захист національних товаровиробників. Також, це один з різновидів наповнення бюджетів, в такому випадку мита виконують фіскальну функцію.

Мито - це обов'язковий особливий вид податку, що стягується митними органами країни при ввезенні товару на іi митну територію або його вивозі 3 цієї території і що $€$ невід'ємною умовою такого ввезення або вивозу відповідно до ії законодавства.

Можна виділити наступні функції функцій мита [2]:

- захисна - передбачає формування бар'єрів, що перешкоджають проникненню товарів на митну територію країни. Митний тарифр за своєю суттю виконує захисну функцію навіть тоді, коли вітчиз- няна продукція не вступає в пряму конкуренцію з іноземними товарами;

- фіскальна - формує доходну частину держав- ного бюджету. Застосування митних платежів завжди виконує фріскальну функцію, оскільки митний тариф завжди є податком;

- регулятивна - формує раціональну структуру експорту та імпорту. За допомогою мита держава може здійснювати контроль над обсягами і харак- тером товаропотоку, тобто стимулювати рух товарів або навпаки;

- політична - здійснює економічний тиск на інші держави чи надає їм митні пільги. Держава стосовно інших країн застосовує економічні заходи, з боку яких, у свою чергу, можлива відповідь за принципом «дія-протидія». Це є однією із форм міжнародної економічної взаємодії.

Мито як і непрямі податки нараховуються на вартість товару впливаючи на його кінцеву ціну, однак це відбувається лише одноразово при перетині кордону (експорті чи імпорті товару). Також, на відмінно від податку на додану вартість мито при його подальшому вивезенні не повертається імпортеру, більш того у значній кількості випадків стягається й експертне мито. Іншими відмінностями від непрямих податків 
$€$ різні ставки в залежності від виду товару та можливість повного або часткового звільнення від сплати мита в залежності від виду товару.

Мита у Європейському Союзі класифікуються за рядом критеріїв (рис. 1), основними з яких є: за характером зовнішньоторговельних операцій, за способом встановлення ставки, сільськогосподарські мита, за цілями стягнення [2].

Необхідно зазначити, що на сьогодні близько $99 \%$ ставок мит розвинутих країн, в тому числі й держав-членів $€ C, \epsilon$ пов'язаними згідно із зобов'язаннями про тарифні поступки в рамках СОT, а їх середньозважена ставка не перевищує 5\% (за винятком сільськогосподарських зборів). Таким чином, абсолютна більшість ставок Єдиного митного тарифу
$€ C €$ конвенційними за своєю сутністю, адже вони встановлені відповідно до міжнародних угод. Дотримуючись домовленостей, досягнутих у ході декількох раундів торговельних переговорів у рамках ГАТТ і СОТ, ЄС послідовно знижує ставки імпортних мит. За даними СОТ, середня ставка мит у ЄС становить 6,9\%, причому, для сільськогосподарської продукції середня ставка дорівнює 17,3\%, для інших товарів (крім бензину) - 4,5\%. Різниця між мінімальною й максимальною ставками мит становить: для сільськогосподарської продукціі від 0 до 236,4\%, для іншої продукції від 0 до 26\%. Крім того, багато товарів одержують в Співтоваристві тарифні преференції.

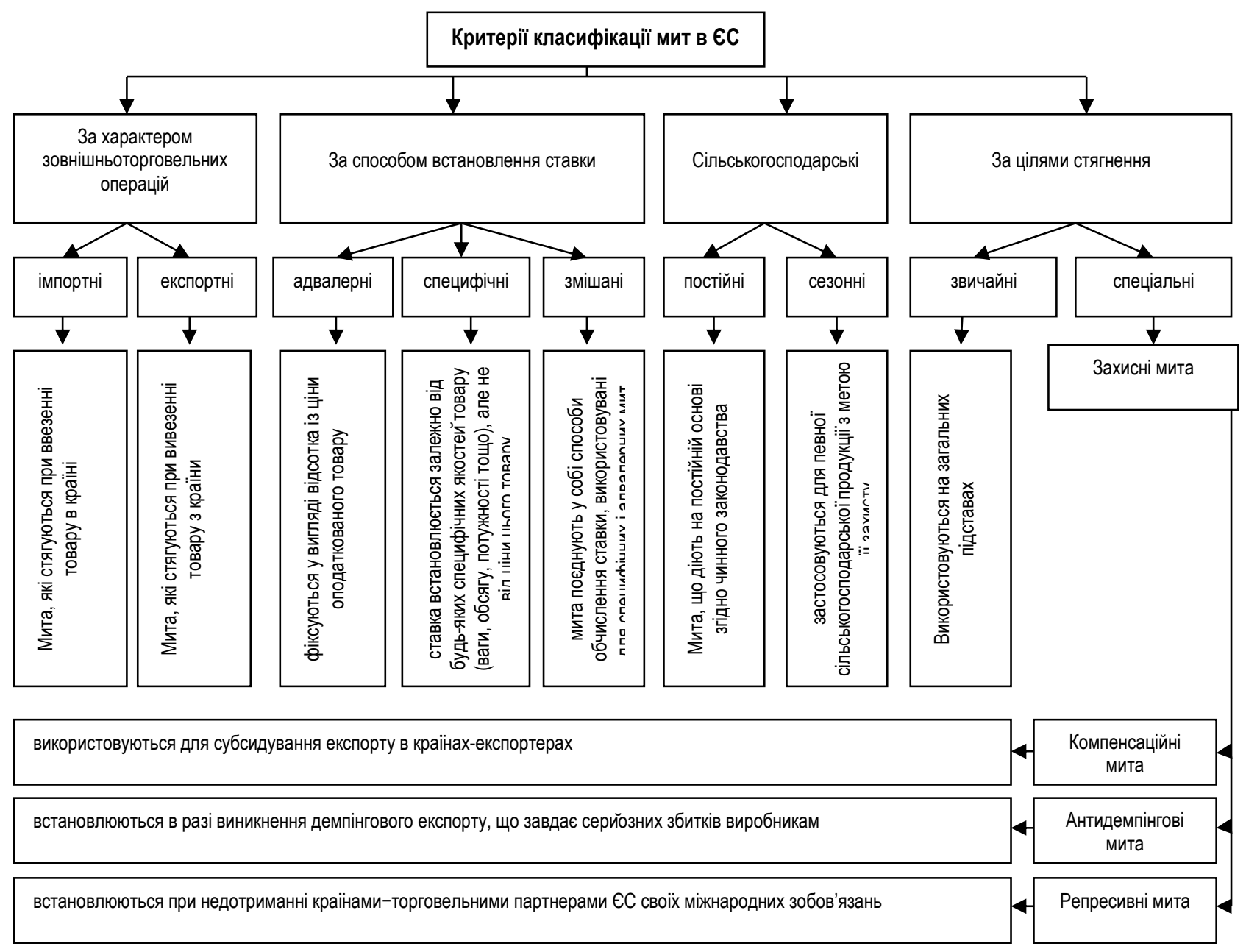

Рис. 1. Критерії клачифікації мит на території ЄС

Митний кодекс ЄС дорівнює до мит збори, що мають рівнозначний ефект. Це дозволяє поширити норми митного права Співтовариства на різні збори, застосовувані Співтовариством і державами-членами поза рамками спільної торговельної політики. При кваліфікації таких зборів Суд ЄС приділяє ключову роль ефекту (наслідкам) зборів, а саме - чи призводить застосування збору до дискримінації іноземних товарів. Відповідно до умов митного союзу, збори, що вводяться державами-членами у відношенні ввезених товарів або товарів, що вивозяться, при наявності ефректу, рівнозначного митам, підлягають забороні [3].

Ще одним видом митних платежів є податки з обігу та акцизи. Основним різновидом податків з обігу в країнах $€ С €$ податок на додану вартість. Характер ПДВ передбачає, що товари внутрішнього виробництва й імпортовані товари підлягають рівному обкладанню, тому ПДВ на імпорт товарів сплачується так само, як і при внутрішньому обігу. Варто зазначити, що з 1 січня 1993 р. при ввезенні товарів з однієі країн ЄС до іншої підстав для обкладання ПдВ не виникає. Збір ПДВ при імпорті товарів у ЄС із третіх країн носить не дискримінаційний (як імпортні мита), а компенсаційний характер, оскільки забезпечує рівність між товарами внутрішнього виробництва й імпортованими. Таким чином, природу ПДВ можна визначити як зрівняльну.

Незважаючи на значні успіхи в гармонізаціїправа держав-членів у галузі непрямого оподатковування, дотепер не 
вирішене питання про введення єдиної ставки ПДВ у Співтоваристві. Ставки ПДВ установлюються державами-членами самостійно, хоча й $з$ дотриманням установлених у Співтоваристві в 1993 р. верхніх і нижніх меж. Тому, якщо мита на імпортований товар можуть стягуватися на всій митній території ЄС по ставці, установленіи Єдиним митним тарифом, то ПДВ повинен стягуватися по ставці, що діє в країні-імпортері. Така ситуація багато в чому суперечить свободі пересування товарів у Співтоваристві, оскільки обмежує можливості імпортерів Співтовариства при виборі місця митного оформлення товарів.

В рамках ЄС запроваджена єдина система оподаткування ПДВ для спрощення переміщення товарів всередині спільноти. Основним документом, що регулює дану сфреру, $\epsilon$ Директива 2006/112/ЄС від 28 листопада 2006 року «Про спільну систему податку на додану вартість» 3 подальшими змінами та доповненнями.

Директива встановлює загальні уніфіковані правила, проте надає країнам-учасницям можливість застосовувати свої винятки із загальних правил у таких важливих питаннях як порядок і умови реєстрації платників податку, категорії товарів та послуг, які оподатковуються за зниженими ставками, розміри цих ставок та ін.

Директива ЄС визначає правила застосування ставок податку на додану вартість.

Країни-члени ЄС можуть самостійно визначати стандартну ставку VAT на своїх територіях, але, згідно з директивою, вона не може бути менше 15\%. Знижені ставки застосовуються до наступних категорій товарів та послуг, визначених у додатках до директиви:

- продукти харчування для людей та тварин;

- постачання води;

- медичне обладнання та фармацевтичні препарати;

- послуги перевезення пасажирським транспортом.

Знижені ставки можуть застосовуватися тільки до категорій товарів і послуг, зафіксованих в даній директиві. Їх перелік та характеристики встановлює держава в рамках своєї юрисдикції. Знижена ставка не може бути менше $5 \%$.

Так, основні ставки ПДВ в країнах ЄС станом на 1 січня 2017р. коливаються: Люксембург - $17 \%$, Мальта - $18 \%$, Німеччина, Кіпр, Румунія - 19 \%, Австрія, Болгарія, Великобританія, Словаччина, Франція, Естонія - 20 \%, Бельгія, Іспанія, Латвія, Литва, Нідерланди, Чехія - $21 \%$, Італія, Словенія - $22 \%$, Ірландія, Польща, Португалія - $23 \%$, Греція, Фінляндія - $24 \%$, Данія, Хорватія, Швеція - 25 \%, Угорщина - $27 \%$ $[5,6]$.

Якщо ПДВ $є$ загальним податком з обігу, то акцизи являють собою приклад спеціального споживчого податку, тому що накладаються тільки на окремі види товарів, які користуються особливим попитом на внутрішньому ринку. У ЄС до категоріїпідакцизних товарів відносяться пиво, вино, міцні алкогольні напої, мінеральні мастила, деякі види палива, тютюнові вироби, деякі предмети розкоші. Відносно оподатковуваних товарів акцизи також носять зрівняльний характер, оскільки поширюються і на внутрішні, і на імпортовані товари даної категорії. Аналогічно ПДВ, з 1 січня 1993 р. акцизи не стягуються при ввезенні підакцизного товару з однієї країни $€ С$ до іншої, але стягуються при імпорті підакцизних товарів на митну територію ЄС. Ставки акцизів установлюються державами-членами на основі гармонізованих правил. На відміну від ПдВ і мита, яке переважно є адвалерним, (тобто, обчислюваним у відсотках від митної вартості товару), акцизи, як правило, являють собою специфічні збори Вони обчислюються у фіксованій ставці на одиницю товару (маси товару, вмісту алкоголю тощо). При експорті підакцизних товарів вартість акцизів, аналогічно ПДВ, повертається експортерам, що передбачено правилами ГАТТ.

Митне законодавство ЄС допускає у ряді випадків стягнення митними органами держав-членів митних зборів як плату за додаткові послуги, надані за запитом декларантів. До таких послуг відносяться:

a) аналіз і експертна оцінка зразків товарів, а також ї̈нє поштове пересилання на запити з питань застосування митного законодавства;

б) зберігання товарів на складах тимчасового зберігання понад установлені строки; клараціі

в) перевірка товару імпортером до подання митноїде-

г) знищення товару, якщо це тягне витрати митних органів;

д) перевірка товарів з метою верифікації, якщо це тягне витрати митних органів;

е) проведення митного оформлення в неробочий час або поза встановленим для цього місцем.

На жаль, можливість гармонізації митного законодавства України за вимогами ЄС суттєво гальмується через надання пріоритету фіскальній функції митних органів, що надзвичайно ускладнює можливість тісної співпраці 3 країнами ЄС. У промислово розвинутих країнах мито виконує перш за все регулюючу функцію, а не фіскальну, і надходження від справляння ввізного мита складають не більше 0,3\% ВВП, на відміну від України, митна служба якої відіграє ваджливу роль в процесі наповнення державного бюджету. Перетворення митних органів України у фіскальні зменшує можливості реалізації їнших їх функцій та створює перешкоди для міжнародного співробітництва та ефективної боротьби з митними правопорушеннями. Як наслідок, збільшуються масштаби ухилення від сплати податків, зменшується конкурентоспроможність вітчизняного товаровиробника, не приділяється належної уваги розвитку співробітництва на міжнародній арені тощо.

Членство України в СОТ, прагнення до членства в Європейському Союзі, а також з огляду на процеси інтеграції в потік міжнародного товарообігу вимагають адаптування норм митного права до стандартів світової спільноти.

Питання порядку справляння митних платежів врегульовані в міжнародних договорах, учасницею яких є і Україна. Серед таких міжнародних угод можна виділити оновлену Конвенцію про спрощення та гармонізацію митних процедур (далі - Конвенція) та Протокол про Єдиний порядок справляння митних платежів в державах учасницях СНД (далі Протокол). В Конвенції передбачено порядок справляння та повернення митних платежів в аспекті функціонування кожного виду митного режиму [70], натомість в Протоколі передбачено порядок, без врахування виду обраного митного режиму. Підхід передбачений в Протоколі, на думку автора, не може сприяти ефективному застосуванню митно-тарифнии заходів регулювання зовнішньої торгівлі.

Застосування єдиного порядку без врахування виду 
митного режиму в недостатній мірі враховує приватні інтереси, які можуть бути реалізовані при здійсненні зовнішньоекономічної діяльності.

Справляння мита в залежності від виду митного режиму дозволить надати перш за все гарантії для приватних суб'єктів через прозорість митного регулювання, а також сприятиме ефективній реалізації завдання митних органів по застосуванню митно тарифних засобів регулювання.

Взірцем порядку справляння мита можуть бути правові рішення митного права ЄС. Інтеграційні процеси в Україні вимагають адаптації національних норм до стандартів Європейської Спільноти, оскільки існування в рамках ЄС митного союзу означає встановлення єдиної митної політики та єдиного митного права для всіх державОчленів.

В нормативному доробку ЄС правові положення щодо порядку справляння митних платежів викладені з врахуванням правил міжнародних нормативних актів, серед яких і положення Конвенції про спрощення та гармонізацію митних процедур.

Підсумовуючи вищезазначене, приходимо до висновку, що основними заходами, спрямованими на підвищення організації роботи з адміністрування митних платежів, є:

- покращення організаційно-правового забезпечення діяльності митних органів;

- обмеження термінів подання висновків експертними підрозділами з метою забезпечення вимог Митного кодексу щодо оформлення повної митної деклараціі;;

- вдосконалення організаційних заходів шляхом: посилення контролю митних органів за правильністю класифікації та визначення країни походження товарів, стосовно яких встановлено ди-фреренціиовані ставки ввізного мита і спеціальні та антидемпінгові заходи;

- проведення аналізу класифрікаційних імпорту та перегляду переліку товарів "групи ризику";

- активізації співпраці з виробниками і імпортерами товарів;

- створення електронної митниці, як багатофункціональної комплексної системи, що поєднує інформаційно-комунікативні технології та сукупність механізмів ї застосування.

Висновки. Вирішення зазначених питань на практичному рівні та використання досвіду Європейського Союзу дозволить підвищити якість митного регулювання та вдосконалити процес адміністрування митних платежів органами Державної митної служби України

\section{Список використаної літератури:}

1.Денисенко В. В. Правове забезпечення митної політики : міжнародно-правові стандарти та українське законодавство : навч. посіб. / В. В. Денисенко - Запоріжжя : ЗНТУ, 2018. - 326 с. 83-87

2.Молчанова А. Митнні платежі як складова доходів Державного бюджету України. Економічні студії, 2017. №5(18). С.

3.Taxation trends in the European Union. 2010 edition Data for the EU Member States and Norway / European Commission. Taxation and customs. Union. Euro stat. - Luxembourg of ce for of cial publications of the European communities. - 2010. - $445 \mathrm{p}$.

4.Пелехатий А.О. Бюджетна політика у забезпеченні розвитку територій: концептуальні домінанти та напрями модернізації: [монографія] / А.О. Пелехатий. Львів: Львівський національний університет імені Івана Франка, 2019. 386 с.

5.Пелехатий А.О. Обгрунтування нової парадигми бюджетної політики розвитку територій в умовах реформування публічних фінансів в Україні. Електронне наукове фахове видання «Ефективна економіка», №7, 2019 [Електронний ресурс]. Режим доступу: http://www.economy.nayka.com.ua/?op=1\&z=7191

\section{References}

1.Denysenko V. V. (2018). Pravove zabezpechennia mytnoi polityky: mizhnarodno-pravovi standarty ta ukrainske zakonodavstvo [Legal Support for Customs Policy: International Legal Standards and Ukrainian Legislation]. Zaporizhzhia: ZNTU, 326 p.

2.Molchanova A. (2017). Mytnni platezhi yak skladova dokhodiv Derzhavnoho biudzhetu Ukrainy [Customs payments as a component of the State Budget of Ukraine]. Ekonomichni studii- Economic Studies. Vol. 5(18). pp. 83-87

3.European Commission. Taxation and customs. Union. Euro stat. (2010). Taxation trends in the European Union. 2010 edition Data for the EU Member States and Norway. Luxembourg of ce for of cial publications of the European communities. $445 \mathrm{p}$.

4.Pelekhatyi A.O. (2019). Biudzhetna polityka u zabezpechenni rozvytku terytorii: kontseptualni dominanty ta napriamy modernizatsii [Budget Policy in Territorial Development: Conceptual Dominants and Directions for Modernization]. Lviv: Lvivskyi natsionalnyi universytet imeni Ivana Franka, 386 p. [in Ukrainian].

5.Pelekhatyi A.O. Obhruntuvannia novoi paradyhmy biudzhetnoi polityky rozvytku terytorii $v$ umovakh reformuvannia publichnykh finansiv $v$ Ukraini [Substantiation of the new paradigm of budgetary policy of territorial development in the context of public finance reform in Ukraine]. Efektyvna ekonomika - Effective Economics, №7. Retrieved from: http://www.economy.nayka.com.ua/?op=1\&z=7191. [in Ukrainian].

Prokipchuk L.I., PhD student, Ivan Franko National University of Lviv (Lviv, Ukraine)

The European Union experience in customs payment administration issues: theoretical basis and practical recommendations

The article explores the experience of the European Union in customs administration issues. The main categories of customs payments are levied within the EU (import duty; export duty; anti-dumping duty; countervailing duty; agricultural duties; value added tax; excise duties). The criteria by which the duties in the EU can be classified (by the nature of foreign trade operations (import, export), by the method of setting rates (ad valorem, specific, mixed), agricultural duties (constant, seasonal), by levies (ordinary, special)) are considered. The basic functions of the duty are defined: protective, fiscal, regulatory, political. The issue of value added tax and excise duty in the countries of the Community has been investigated. Indicates the main value added tax rates in the European 
Union (Luxembourg - 17\%, Malta - 18\%, Germany, Cyprus, Romania - 19\%, Austria, Bulgaria, United Kingdom, Slovakia, France, Estonia - 20\%, Belgium, Spain, Latvia, Lithuania, Netherlands, Czech Republic - 21\%, Italy, Slovenia - 22\%, Ireland, Poland, Portugal - 23\%, Greece, Finland - 24\%, Denmark, Croatia, Sweden - 25\%, Hungary - 27\%.). The types of services for which the customs legislation of the EU allows in some cases of collection by customs authorities of the Member States of customs duties as payment for additional services are specified, namely: analysis and expert evaluation of samples of goods; storage of goods in temporary storage warehouses for a longer period; inspection of the goods by the importer before submission of the customs declaration; destruction of the goods if this entails the expense of the customs authorities; inspection of goods for verification purposes, if this entails the expense of customs authorities; Carrying out customs clearance during off-hours or outside the designated place. The measures are proposed to increase the organization of work on the administration of customs payments in EU countries.

Key words: customs duties, value added tax, excise duties, administration, European Union.

Дата надходження до редакції: 27.08.2019 р. 